\title{
Effect of Resveratrol on Dipeptidyl Peptidase-4 (DPP-4) and Phospho Enol Pyruvate Carboxy Kinase (PEPCK) in Streptozotocin -Induced Diabetic Rats
}

\author{
Salwa EI Meligy, Manal EI Batch, Ghada Abd EI Alem \\ Medical Biochemistry Department, Faculty of Medicine Tanta University
}

\begin{abstract}
The aim of the present study was to determine the effect of resveratrol on dipeptidyl peptidase 4 (DPP-4) and phosphoenolpyruvate carboxykinase (PEPCK) enzyme activities in streptozotocin (STZ) induced diabetic rats, trying to find an explanation for its hypoglycemic effect. Sixty male Wistar Albino rats were included in the present study and classified into three groups, group I (control,non-diabetic), group II (diabetic group),group III (diabetic rats treated with resveratrol, $5 \mathrm{mg} / \mathrm{kg}$ body weight/day) for 30 days. After 30 days, blood was collected for determination of; serum glucose, insulin and DPP-4 enzyme activity. The liver was excised for estimation of liver glycogen and PEPCK enzyme activity. Serum glucose, DPP-4 activity, and liver PEPCK activity were significantly increased but serum insulin and liver glycogen were significantly decreased in STZ treated group, while upon resveratrol treatment, they were all reversed with no significant difference between group I and group III ( except for final fasting serum glucose level). Conclusion the antihyperglycemic effect of resveratrol may be related to its stimulatory effect on insulin, its suppressive effect on :either DPP-4, so increases the level of incretins with subsequent increase in insulin release followed by lowering blood glucose level, or its inhibitory effect on PEPCK enzyme activity and subsequent decrease in gluconeogenesis, or, finally its stimulation of glucose utilization by increasing glycogen formation.
\end{abstract}

\section{INTRODUCTION}

Diabetes mellitus is a group of metabolic disorders characterized by hyperglycemia, dyslipidemia, and altered protein metabolism. Altered rates of gluconeogenesis are responsible for increased hepatic glucose output and therefore, sustained hyperglycemia in both IDDM and NIDDM.(1)

Insulin activates glycogen synthesis and suppresses gluconeogenesis and glycogenolysis by affecting post-translational modification of the key enzymes and their gene expression ${ }^{(2)}$

A key step in gluconeogenesis is the formation of phosphoenolpyruvate from oxaloacetate, which is catalyzed by phosphoenolpyruvate carboxykinase (PEPCK) enzyme. Augmented activity of PEPCK enzyme contributes to the maintenance of elevated plasma 
glucose in chemically induced diabetes $^{(3)}$.

Dipeptidyl peptidase-4 (DPP-4, EC 3.4.14.5) exists on the surface of various types of cells, and in a soluble form in plasma. DPP-4 is a serine protease, which cleaves the penultimate L-proline or L-alanine at the N-terminus of several polypeptides, such as glucagon-like peptide 1 (GLP-1) and glucosedependent insulinotropic polypeptide $(\mathrm{GIP})^{(\mathbf{4}, \mathbf{5})}$. These peptides augment nutrient-induced insulin release from pancreatic $\beta$-cells. Their cleavage can be blocked by specific DPP-4 inhibitors, resulting in increased plasma concentrations of the intact peptides and improved glucose tolerance ${ }^{(6,7)}$.

Resveratrol is one of naturally occurring phytochemicals produced by a wide diversity of plants such as grapes, peanuts and mulberries. It has a variety of biological and pharmacological effects including anti-inflammatory, antioxidant, anticarcinogenic and cardio-protective activities $^{(\mathbf{8})}$. It ameliorates common diabetes symptoms, such as polyphagia, polydipsia, and body weight loss. Several studies have shown that resveratrol possesses hypoglycemic and hypolipidemic effects in STZ induced diabetic rats. ${ }^{(\mathbf{8 , 9}, 10)}$ Mechanism of antihyperglycemic effect of resveratrol in STZ- induced diabetic rats is still unclear. So, the aim of the present study was to determine the effect of resveratrol on DPP-4 and PEPCK activities in STZ -induced diabetic rats, to find an explanation for its hypoglycemic effect

\section{MATERIALS \& METHODS}

\section{Chemicals}

Most chemicals including STZ and resveratrol were purchased from Sigma Aldrich Chemical Co., St. Louis, MO, USA, stored at $2-4{ }^{\circ} \mathrm{C}$ and protected from sunlight.

\section{Animals}

\subsection{Experimental animals and diets}

This study was carried out on 60 male Wister albino rats of approximately $(90-140$ g) body weight. During the study, animals were housed in wire mesh cages and were fed standard rat chew and allowed free access to water. They were kept under constant environmental conditions $\left(25^{\circ} \mathrm{C}\right.$ and 12 hour dark light cycle). All animals were weighed at the beginning and at the end of the study. (Dead rats were excluded from the study)

\subsection{Induction of diabetes}

Induction of diabetes was made by a single intraperitoneal injection of STZ at a dose of $70 \mathrm{mg} / \mathrm{kg}$ body weight in freshly prepared ice-cold citrate buffer $(0.1 \mathrm{M} \mathrm{pH} 4.0)$ for 3 consecutive days. STZ was used to induce damage to pancreatic beta cells and produce type I diabetes. Diabetes was defined as a blood glucose level greater than $250 \mathrm{mg} / \mathrm{dl}$ (11) using a drop of blood obtained by a tail-vein puncture monitored at different time intervals throughout the study using glucocheck method strips (Roche Diagnostics GmbH, Germany).

\subsection{Animal treatment}

- After induction of diabetes (within 72 hours after STZ injection), diabetic rats were divided into two groups with 20 rats in each group. One group was maintained on a 
standard diet (untreated-diabetes group; G-II), another one was treated with resveratrol $(5 \mathrm{mg} / \mathrm{kg}$ body weight/day) dissolved in saline and given orally and repeated daily until the end of the study (30 days) (resveratrol-diabetic treated group; G-III) according to Palsamy and Subramanian ${ }^{(\mathbf{1 1})}$, in addition to 20 rats received an intraperitoneal injection of a single dose of 0.1 $\mathrm{mol} / \mathrm{L}$ sodium citrate buffer $(\mathrm{pH}$ 4.5) (normal control group; G-I)

- Body weight and blood glucose were determined at regular intervals throughout the experiment.

- The dosage of resveratrol was adjusted every week according to the body weight.

- At the end of the treatment period, the rats were fasted overnight, and then sacrified by cervical decapitation. Both blood and liver tissues were collected for the following biochemical analysis

\section{Biochemical analysis}

\subsection{Blood samples}

They were collected into dry sterile centrifuge tubes, centrifuged for 10 minutes at $5000 \mathrm{rpm}$. Serum was separated and divided into two parts; one used for immediate glucose estimation using a commercial kit supplied by Elitech Diagnostics Company, France ${ }^{(\mathbf{1 2})}$, and the other part stored in aliquots at $-20^{\circ} \mathrm{C}$ until analysis for measurement of :

1. Serum DPP-4 activity was determined with the "direct photometric method" adapted to 96well plates. According to Hino et al., $1976^{(\mathbf{1 3})}$, in which the reaction mixture contained $50 \mu \mathrm{l}$ of $0.3 \mathrm{M}$ Glycine / NaOH buffer ( $\mathrm{pH} 8.7$ ), $100 \mu \mathrm{l}$ of $3 \mathrm{mM}$ Gly-Pro- $\rho-$ nitroanilide $\rho$-toluenosulfonate (Sigma G 2901),50 $\mu 1$ distilled water and $10 \mu \mathrm{l}$ serum. Instead of serum, blank and standard wells contained $10 \mu \mathrm{l}$ distilled water and $10 \mu 1$ of $3 \mathrm{mM} \rho$-nitroanilide (Sigma N2128) respectively. Control wells contained no serum. After $30 \mathrm{~min}$ of incubation at $37^{\circ} \mathrm{C}$, the reaction was stopped by adding $50 \mu \mathrm{l}$ of chilled $\left(4^{\circ} \mathrm{C}\right) 1 \mathrm{M}$ acetate buffer $(\mathrm{pH} 4.2)$, $10 \mu \mathrm{l}$ serum was added to control wells. Absorbance was measured at $405 \mathrm{~nm}$ with microplate reader (Stat fax 2100, Awareness Technology, Inc, Palm City, USA). Calculations were made after adjusting measurements with the blank, enzyme activity was calculated using the following equation: $100 \times$ $(\mathrm{E}-\mathrm{C}$ ) /S (where E, C and S are absorbance of experimental, control and standard samples, respectively). One unit of enzyme activity was defined as the amount of enzyme liberating $1 \mu \mathrm{mol}$ of product (i.e. $\rho$ nitroanilide) per minute per liter of serum at $37^{\circ} \mathrm{C}$ and it is expressed in $(\mathrm{U} / \mathrm{L})$. All experiments were made in duplicates

2. Serum insulin level was estimated by an enzyme linked immunosorbant assay (ELISA) using a commercial kit supplied by BioSource Multispecies, California $^{(14)}$.

\subsection{Tissue samples}

The liver was excised, washed with ice cold saline to remove extraneous materials, weighed, cut into small pieces and immediately stored at -70 C till used for :

- One portion used for assessment of glycogen content according to Scifter et al., $1950^{(\mathbf{1 5})}$. The liver tissue was 
homogenized in 5 vol of a $30 \%$ (wt/vol) $\mathrm{KOH}$ solution and dissolved at $100^{\circ} \mathrm{C}$ for 30 minutes. The glycogen concentration depends on the formation of a green colour by the reaction of the sugars with anthrone reagent under acidic conditions and the absorbance was measured at 620 nm.

- Another portion was minced and homogenized with a potter Elvenhjem tissue homogenizer in $50 \mathrm{mM}$ Tris HCL buffer $\mathrm{pH} 7.4$ in a ratio of $1 / 5$ $\mathrm{w} / \mathrm{v}$. The crude homogenate was centrifuged at 7,700 $\mathrm{x} \mathrm{g}$ for 30 minutes at $4^{\circ} \mathrm{C}$, and the resultant supernatant (free of insoluble materials) was stored at $-70^{\circ} \mathrm{C}$ till use for estimation of:

1- PEPCK enzyme activity spectrophotometrically by coupling the conversion of phosphoenol pyruvate to oxalacetate by PEPCK and the subsequent conversion to malate by malate dehydrogenase according to Petrescu et al., $1979^{(\mathbf{1 6})}$. In this method deoxy guanosine di-phosphate (dGDP) is preferred as it is the only nucleotide acting as good phosphate acceptor for PEPCK, in the same time being a very poor substrate for pyruvate kinase, that interferes seriously in the coupled assay system with malate dehydrogenase. The liver supernatant was pipetted with a reaction mixture $(\mathrm{pH}$ 7.4) containing the following in $1 \mathrm{ml}$ final volume :50 mM Tris HCL buffer (pH 7.4), $0.5 \mathrm{mM}$ phosphoenol pyruvate, $20 \mathrm{mM}$ Sodium bicarbonate ,1 mM $\mathrm{MnCL}_{2}, 0.1$ $\mathrm{mM} \mathrm{NADH}, 2$ units of malate dehydrogenase. The reaction was initiated with $1 \mathrm{mmol} / \mathrm{L}$ of dGDP.

The enzyme activity was measured for 2 minutes at $25^{\circ} \mathrm{C}$ based on a decrease in absorption at 340 . The enzyme activity was expressed as micro units per mg of protein in liver supernatant $(1 \mu \mathrm{U}=$ $\mu \mathrm{mol}$ of oxalacetate $/ \mathrm{min} / \mathrm{mg}$ protein)

2- Protein content, according to Bradford method with bovine serum albumin as a standard ${ }^{(\mathbf{1 7})}$

- A third portion was used for histopathological examination. The liver was fixed in neutral buffered formalin solution (10\%) and dehydrated in a graded series of ethanol, cleared in xylol and impregnated in soft paraffin for 2 hours at $56{ }^{\circ} \mathrm{C}$ then embedded in hard paraffin. Sections of $4 \mu \mathrm{m}$ thickness were cut by the microtome and stained with hematoxylin and eosin (H\&E). The tissues were observed using an optical microscope.

\section{Statistical Analysis}

All the data were expressed as mean \pm standard deviation (SD). Statistical analysis was done using one-way analysis of variance (ANOVA), and post-hoc comparisons were carried out using Tukey's t-test. The Pearson correlation test was used to find out the correlation between the studied parameters. $\mathrm{P}$ values $<0.05$ were considered as significant.

\section{RESULTS}

Table (1) shows a comparison between all the studied groups as regard all the studied parameters, in which both serum glucose, DPP-4 activity, and liver PEPCK activity 
were significantly increased but serum insulin and liver glycogen were significantly decreased in STZ treated group, while upon resveratrol treatment, they were all reversed with no significant difference between group I and group III( except for final fasting serum glucose level), but final body weight was significantly lower in group II and III than in group I with no significant difference between group II and group III so, diabetic rats treated with resveratrol failed to gain weight in a significant manner as all diabetic rats were smaller than those of control group. Table (2) showed that both DPP-4 and PEPCK were significantly positively correlated with serum blood glucose but significantly negatively correlated with serum insulin level. Figure (1) shows liver histopathological changes of normal control, with normal hepatocytes and rounded nuclei forming hepatic cell cords radiating from the central vein. Figure (2) shows liver histopathological changes of diabetic rats exhibiting marked fatty degeneration, granular hyaline degeneration, and mild inflammation. Figure (3) shows liver histopathological changes of diabetic rats treated with resveratrol presenting normalization of hepatocytes arrangement around the central vein with declined fat accumulation and decreased central vein dilatation.

Table (1): comparison between the studied groups as regards all the studied parameters

\begin{tabular}{|l|l|l|l|l|}
\hline Variables & $\begin{array}{l}\text { Group I } \\
\mathbf{( n = 2 0 )} \\
\text { Mean } \pm \text { SD }\end{array}$ & $\begin{array}{l}\text { Group II } \\
\text { (n=20) } \\
\text { Mean } \pm \text { SD }\end{array}$ & $\begin{array}{l}\text { Group III } \\
\text { (n=20) } \\
\text { Mean } \pm \text { SD }\end{array}$ & P \\
\hline Final body weight (gm) & $152 \pm 18.1$ & $100 \pm 21.3$ & $109.4 \pm 16.5$ & $\begin{array}{l}<0.001^{*} \text { All groups are } \\
\text { significant except II vs. III }\end{array}$ \\
\hline $\begin{array}{l}\text { Final fasting serum } \\
\text { glucose level (mg/dl) }\end{array}$ & $82.5 \pm 12.5$ & $429.9 \pm 53.9$ & $193.7 \pm 52.7$ & $\begin{array}{l}<0.001^{*} \text { All groups are } \\
\text { significant }\end{array}$ \\
\hline Serum DPP-4 (U/L) & $29.4 \pm 5.5$ & $67.9 \pm 10.7$ & $35.47 \pm 7.7$ & $\begin{array}{l}<0.001^{*} \text { All groups are } \\
\text { significant except I vs. III }\end{array}$ \\
\hline Serum insulin $\boldsymbol{\mu I U / m I}$ & $34.9 \pm 7.6$ & $13.2 \pm 3.3$ & $32.34 \pm 7.6$ & $\begin{array}{l}<0.001^{*} \text { All groups are } \\
\text { significant except I vs. III }\end{array}$ \\
\hline $\begin{array}{l}\text { Liver glycogen } \mathbf{~ m g / g m ~} \\
\text { liver }\end{array}$ & $84.5 \pm 12.6$ & $42.3 \pm 4.3$ & $78.2 \pm 12.9$ & $\begin{array}{l}<0.001^{*} \text { All groups are } \\
\text { significant except I vs. III }\end{array}$ \\
\hline $\begin{array}{l}\text { PEPCK } \boldsymbol{\mu m o l} / \mathbf{m i n} / \mathbf{m g} \\
\text { protein }\end{array}$ & $11.3 \pm 5.7$ & $31.7 \pm 5.3$ & $9.7 \pm 1.4$ & $\begin{array}{l}<0.001^{*} \text { All groups are } \\
\text { significant except I vs. III }\end{array}$ \\
\hline
\end{tabular}

Group I (normal control group), Group II (untreated- STZ diabetic group), Group III (resveratrol- STZ diabetic treated group), dipeptidyl peptidase 4 (DPP-4), phosphoenolpyruvate carboxykinase (PEPCK). Data were expressed as mean \pm standard deviation (SD). 
Table (2): Correlation between different parameters in diabetic groups (group II, III n=40).

\begin{tabular}{|c|c|c|c|c|}
\hline \multicolumn{2}{|l|}{$\begin{array}{l}\text { Group II+III } \\
(n=40)\end{array}$} & $\begin{array}{l}\text { Serum } \\
\text { glucose } \\
\text { mg/dl } \\
\end{array}$ & $\begin{array}{l}\text { Serum } \\
\text { DPP-4 } \\
(\mathbf{U} / \mathbf{L})\end{array}$ & $\begin{array}{l}\text { PEPCK } \\
\mu \mathrm{mol} / \mathrm{min} / \mathrm{mg} \\
\text { protein }\end{array}$ \\
\hline \multirow{2}{*}{ Serum glucose mg/dl } & $\mathrm{r}$ & ------ & 0.959 & 0.872 \\
\hline & P-value & ------ & $<0.001^{*}$ & $<0.001^{*}$ \\
\hline \multirow{2}{*}{ Insulin $\mu \mathrm{IU} / \mathrm{ml}$} & $\mathrm{r}$ & -0.893 & -0.854 & -0.807 \\
\hline & P-value & $<0.001^{*}$ & $<0.001 *$ & $<0.001^{*}$ \\
\hline \multirow{2}{*}{ Liver glycogen } & $\mathrm{r}$ & -0.878 & -0.834 & -0.910 \\
\hline & P-value & $<0.001^{*}$ & $<0.001 *$ & $<0.001^{*}$ \\
\hline \multirow{2}{*}{ Serum DPP-4 (U/L) } & $\mathrm{r}$ & 0.959 & --- & 0.785 \\
\hline & P-value & $<0.001^{*}$ & ---- & $<0.001^{*}$ \\
\hline \multirow{2}{*}{ PEPCK $\mu \mathrm{mol} / \mathrm{min} / \mathrm{mg}$ protein } & $\mathrm{r}$ & 0.872 & 0.785 & $\begin{array}{ll}---- \\
\end{array}$ \\
\hline & P-value & $<0.001^{*}$ & $<0.001 *$ & ----- \\
\hline
\end{tabular}

Dipeptidyl peptidase 4 (DPP-4) and phosphoenolpyruvate carboxykinase (PEPCK)

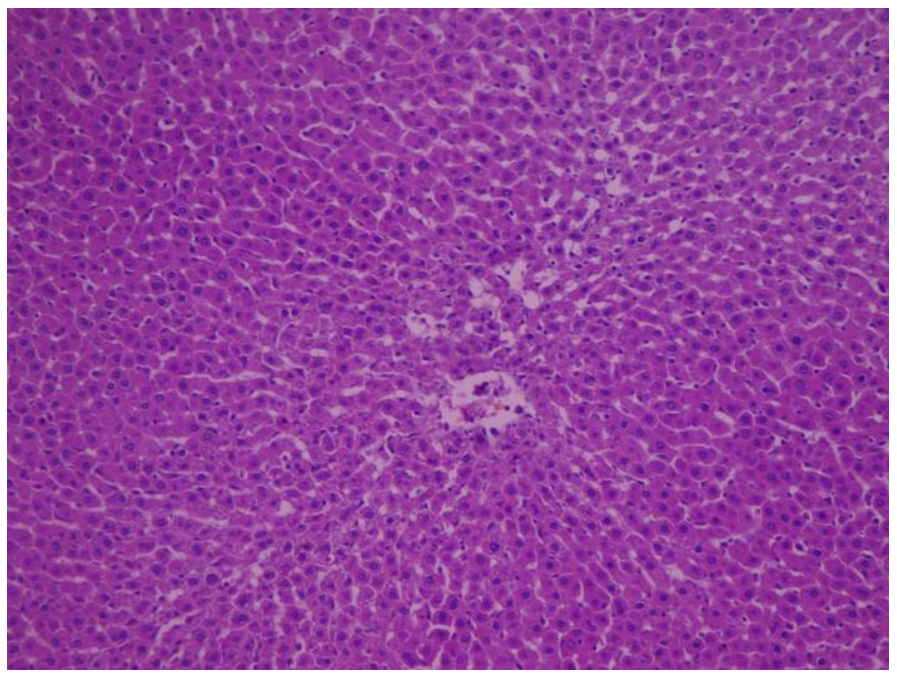

Figure (1): Histopathological changes of liver tissue of control group (Group I).

Light microscopical picture of control liver tissue, showing the normal hepatocytes with rounded nuclei forming hepatic cell cords radiating from the central vein. 


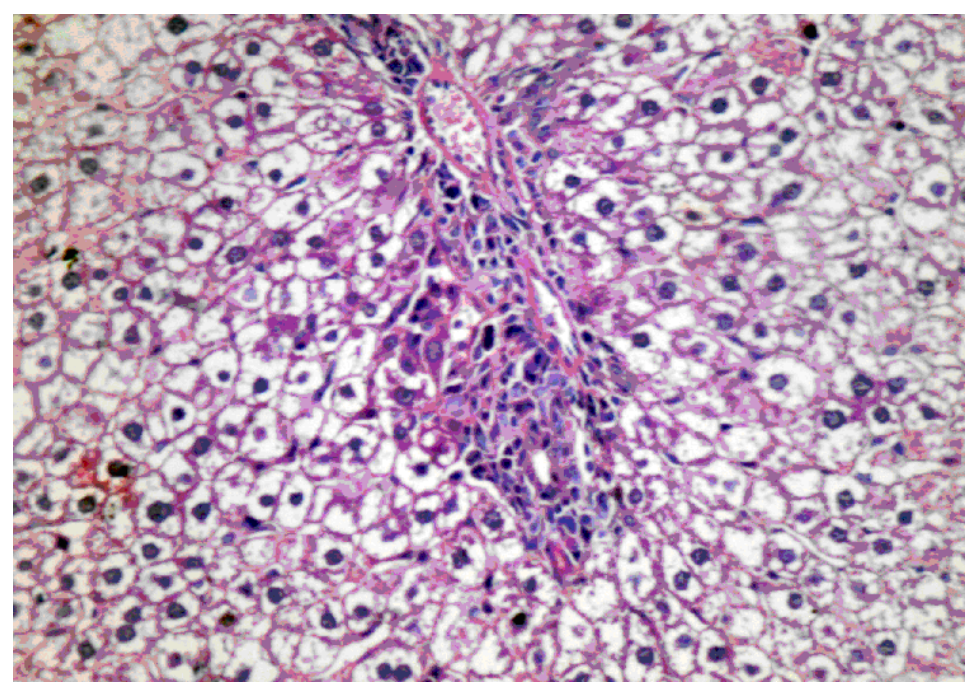

Figure (2): Histopathological changes of liver of STZ diabetic group (Group II).

Liver tissue of diabetic rat, showing the hypertrophied and vacuolated hepatic cells with heavy cellular infiltration and areas of focal necrosis.

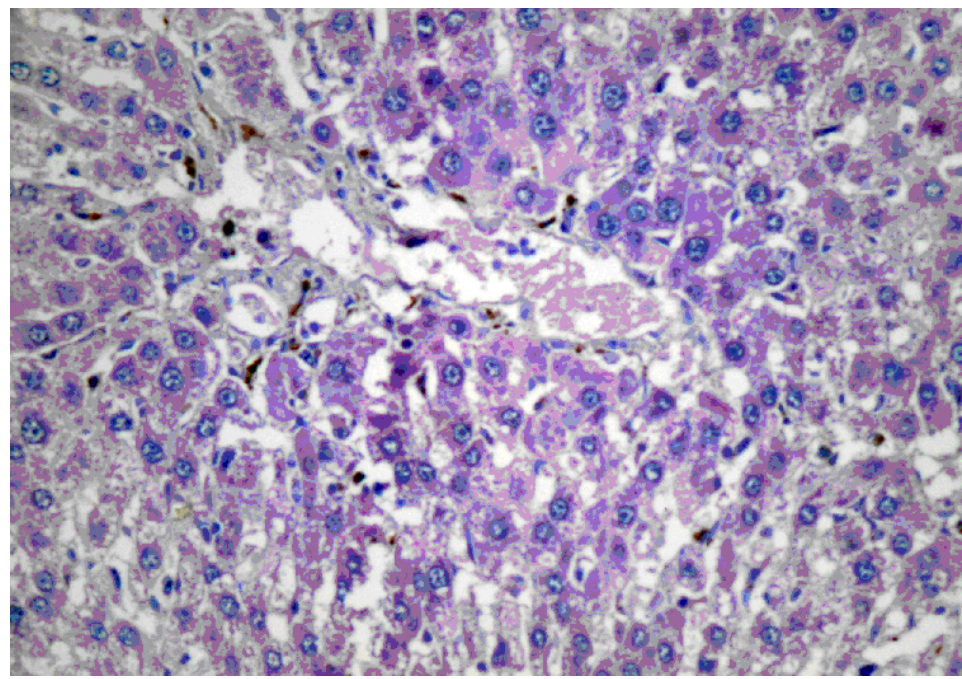

Figure (3): Histopathological assessment of STZ diabetic liver treated with resveratrol (Group III).

Liver tissue of diabetic rat treated with resveratrol showing the apparently normal hepatic cells with few inflammatory cells 


\section{DISCUSSION}

Pharmacological intervention in diabetes focuses on a series of targets, including $\mathbf{B}$-cell function, insulin sensitivity in the muscle, and glucose output in the liver. Many of these hypoglycemic agents showed restricted efficacy and certain adverse effects, therefore, there is a need for phytochemicals that have antihyperglycemic potential and are safe without long-term side effects ${ }^{(\mathbf{1 8})}$.

In the current study there was a significant increase in fasting serum glucose level but a significant decrease in serum insulin level and liver glycogen in STZ induced diabetic group which was reversed upon resveratrol treatment.

STZ potentially damages the pancreatic $\beta$-cells resulting in an apparent decline in insulin levels which is responsible for the decreased liver glycogen levels and subsequently, hyperglycemia ${ }^{(19)}$.

The sustained hyperglycemia may cause reduced number of glucose transporters, down regulation in insulin receptors number as well as defects of tissue insulin signal transduction. Subsequent to these deteriorations, there is an absolute increase in hepatic glucose output, which exceeds an increase of glucose utilization, and fasting hyperglycemia occurs $^{(\mathbf{2 0})}$. The glucose-lowering properties of resveratrol in STZinduced diabetic rats in the present study may be due to the direct stimulatory effects of resveratrol on glucose uptake in soleus muscle, adipocytes and hepatocytes, or due to increase in insulin secretion via its effect on the ATP/ADP ratio that induces depolarization of the plasma membrane and triggers insulin secretion $^{(\mathbf{9}, 11,18,21)}$. Chi et al., 2007 $7^{(\mathbf{8})}$ revealed that resveratrol could produce a hypoglycaemic effect in insulin-deficient STZ-diabetic rats via phosphatidylinositol-3-kinase (PI3K)Akt-signaling pathway to enhance glucose uptake into skeletal muscle, also, it may result in an increase in GLUT4 expression in skeletal muscle and a decrease PEPCK expression in the liver.

Despite recognition of the critical role that PEPCK exerts in controlling gluconeogenesis in the liver, the validation of this enzyme as a target for pharmacological intervention in diabetes has not been extensively investigated. Therefore, the effect of resveratrol on PEPCK was studied. In the present study, PEPCK activity was significantly increased in STZ treated group as compared with the control group and significantly decreased upon resveratrol treatment with no significant difference with the control group. These results came in agreement with Anand et al., 2010 (22) Chang et al., 2003 ${ }^{(23)}$ and Giffin et al., $1993^{(24)}$ who stated that insulin deficiency is clearly associated with increased expression of liver PEPCK via increasing PEPCK mRNA level . Also, Shao et al., 2005 ${ }^{(25)}$ concluded that sustained hyperglycemia diminishes the ability of glucose to inhibit gluconeogenesis and PEPCK gene expression and augments hormone-induced PEPCK gene expression. The effect of resveratrol on PI3K-Akt-signaling pathway not only decrease the plasma glucose of 
insulin-deficient STZ-diabetic rats, but also, could contribute to its lowering effect on hepatic PEPCK level. ${ }^{(\mathbf{8})}$

Apart from the hypoglycemic effect of resveratrol, another metabolic consequence is demonstrated in this study, in which liver glycogen was significantly increased upon resveratrol treatment, which may be due to increase glycogen synthase or due to reduced glycogen phosphorylase activities in the liver of diabetic rats with a concomitant increase in liver glycogen stores ${ }^{(11)}$. So, resveratrol may induce glucose utilization by conversion of glucose into glycogen, although the exact mechanism was not elucidated.

As regards DPP-4 activity in the current study, its activity was significantly increased in STZ induced diabetic rats as compared with control group. In various published clinical reports over the last decade, circulating DPP-4 activity has been reported to be either unchanged $^{(26)}$, decreased ${ }^{(27)}$ or increased ${ }^{(\mathbf{6 , 2 8})}$ in diabetic patients. The results of the present study came in agreement with Ryskjaer et al., $2006^{(28)}$, Mannucci et al., 2005 ${ }^{(6)}$ and Pala et al., $2003^{(29)}$ who showed that prolonged exposure to high glucose is capable of increasing DPP-4 expression and biosynthesis, confirming the stimulatory effect of chronic hyperglycaemia on enzyme activity with still unclear mechanisms; alternatively, endothelial damage induced by hyperglycaemia could cause DPP-4 to leak into the circulation. Finally, hyperosmolarity and/or non-enzymatic glycation could modify circulating enzyme activity ${ }^{(29)}$.

Varga et al.,2010 ${ }^{(4)}$ concluded that increased serum DPP-4 enzyme activity in type 1 diabetes mellitus may refer to pancreatic autoimmune process, concomitant autoimmune diseases, hormonal feed back mechanism, or even target organ damage.

In addition, Kirino et al., $2009^{(30)}$ examined the role of DPP-4 in the development of diabetes, dyslipidaemia and renal dysfunction induced by STZ and found that plasma DPP-4 activity increased progressively with time after STZ treatment in wild-type rats and it was positively correlated to blood glucose.

Finally, the increased activity of plasma DPP-4 could still worsen hyperglycaemia since DPP-4 activation may lead to decrease in the anti-diabetic effects of GLP-1 and GIP; therefore, it was supposed that DPP-4 inhibition was effective in ameliorating STZ-induced metabolic abnormalities $^{(31)}$.

In the present study upon resveratrol treatment, serum DPP-4 activity was significantly decreased as compared with diabetic group but with no significant difference between it and control group.

To our knowledge, this is the first study studied the effect of resveratrol on DPP-4 in STZ induced diabetic rats. The down-regulation mechanism of resveratrol on DPP-4 may be mediated by a novel cell-surface mechanism that induces an increase in protein tyrosine phosphatase activity that may lead to a decrease in the tyrosine phosphorylation of ERK1/2 MAPK resulting in inhibition of Akt 
kinase and Erk1/2 MAPK that in turn links to the decline in DPP-4 mRNA and protein ${ }^{(32,33)}$

In the present study, serum DPP4 and liver PEPCK activity were significantly positively correlated with final fasting serum glucose level and significantly negatively correlated with serum insulin level. These results came in agreement with Kirino et al., 2009(30)who demonstrated that plasma DPP-4 activity levels correlate positively with plasma glucose and HbAlc and negatively with plasma insulin levels, raising the possibility that endogenous DPP-4 activity may influence glucose homeostasis by altering the levels of intact (insulinotropic) incretin hormones

In the present study an insignificant gain in body weight was observed upon resveratrol treatment to diabetic group similar to Palsamy and Subramanian $2008^{(9)}$ who suggested that the improvement in body weight gain in diabetic rats supplemented with resveratrol may be due to improvement of sugar and lipid metabolism in these animals.

\section{CONCLUSION}

the antihyperglycemic effect of resveratrol may be related to its stimulatory effect on insulin, its suppressive effect on: either DPP-4, so increases the level of incretins with subsequent increase in insulin release followed by lowering blood glucose level, or its inhibitory effect on PEPCK enzyme activity and subsequent decrease in gluconeogenesis, or, finally its stimulation of glucose utilization by increasing glycogen formation.

\section{Recommendation}

Further studies are needed to determine, the effect of resveratrol on PEPCK and DPP-IV gene expression to confirm its inhibitory effect at the level of the gene.

\section{REFERENCES}

1. American Diabetes Association, Diagnosis and classification of diabetes mellitus (2010): Diabetes Care; 33 (Suppl. 1): S62-S69.

2. Ramnanan CJ, Edgerton DS, Rivera N, Irimia-Dominguez $\mathbf{J}$, Farmer B, Neal DW, Lautz M, Donahue EP (2010). Molecular characterization of insulinmediated suppression of hepatic glucose production in vivo. Diabetes;59(6):1302-11.

3. Yabaluri N, Bashyam MD (2010): Hormonal regulation of gluconeogenic gene transcription in the liver. J Biosci. 2010 Sep;35(3):473-84.

4. Varga T, Firneisz G, Nagy G, Somogyi A (2010): Elevated serum dipeptidyl peptidase-4 activity in type 1 diabetes mellitus: a direct comparison. Orv Hetil. 30;151(22):899-902.

5. Havre PA, Abe M, Urasaki Y, Ohnuma K, Morimoto C, Dang NH (2008): The role of CD26/dipeptidyl peptidase IV in cancer. Front Biosci.;13:1634-45.

6. Mannucci E, Pala L, Ciani S, Bardini G, Pezzatini A, Sposato I, Cremasco F, Ognibene A, Rotella CM (2005): Hyperglycaemia increases dipeptidyl peptidase IV activity in 
diabetes mellitus. Diabetologia ;48(6):1168-72.

7. Deacon CF, Ahren B and Holst JJ (2004): Inhibitors of dipeptidyl peptidase IV: a novel approach for the prevention and treatment of Type 2 diabetes? Expert Opinion on Investigational Drugs; 13: 1091-1102.

8. Chi TC, Chen WP, Chi TL, Kuo TF, Lee SS, Cheng JT, Su MJ (2007): Phosphatidylinositol3-kinase is involved in the antihyperglycemic effect induced by resveratrol in streptozotocininduced diabetic rats. Life Sci ;80(18):1713-20.

9. Palsamy $\mathbf{P}$, Subramanian $\mathbf{S}$ (2008): Resveratrol, a natural phytoalexin, normalizes hyperglycemia in streptozotocinnicotinamide induced experimental diabetic rats. Biomed

Pharmacother.;62(9):598-605.

10. Palsamy $P$, Sivakumar S, Subramanian S (2010): Resveratrol attenuates hyperglycemia-mediated oxidative stress, proinflammatory cytokines and protects hepatocytes ultrastructure in streptozotocin-nicotinamideinduced experimental diabetic rats. Chem Biol Interact; 186(2):200-10.

11. Palsamy $P$, Subramanian $S$ (2009): Modulatory effects of resveratrol on attenuating the key enzymes activities of carbohydrate metabolism in streptozotocin-nicotinamideinduced diabetic rats. Chem Biol Interact;179(2-3):356-62
12. Trinder $P$ (1969): Determination of blood glucose using an oxidase-peroxidase system with a non-carcinogenic chromogen. J Clin Pathol ;22 :158-161.

13. Hino M, Fuyamada H, Hayakawa T, Nagatsu T, Oya H, Nakagawa Y, (1976): Xprolyl dipeptidyl-aminopeptidase activity, with X-proline pnitroanilides as substrates, in normal and pathological human sera. Clin Chem ;22:1256-1261.

14. Flier JS, Kahn CR, Roth J (1979): Receptors, antireceptor antibodies and mechanisms of insulin resistance. $\mathrm{N}$ Engl $\mathrm{J}$ Med;300(8):413-9.

15. Seifter S., Dayton S., Novic B. \& Muntwyler E (1950): The estimation of glycogen with the anthrone reagent. Arch. Biochem. Biophys;50: 191-200.

16. Petrescu I., Bojan O., Saied M., Bârzu O., Schmidt F. \& Kühnle HF (1979): Determination of phosphoenolpyruvate

carboxykinase activity with deoxyguanosine 5'-diphosphate as nucleotide substrate. Anal Biochem ; 96:279-281.

17. Bradford M.M (1976): A rapid and sensitive method for the quantitation of microgram quantities of protein utilizing the principle of protein-dye binding Anal. Biochem ;72: 248-254.

18. Su HC, Hung LM, Chen JK (2006): Resveratrol, a red wine antioxidant, possesses an insulinlike effect in streptozotocininduced diabetic rats. Am $\mathrm{J}$ Physiol Endocrinol Metab.; 290(6):E1339-46. 
19. Pederson B.A., Schroeder J.M., Parker G.E., Smith M.W., DePaoli-Roach A.A. \& Roach P.J (2005): Glucose metabolism in mice lacking muscle glycogen synthase, Diabetes; 54 : 34663473.

20. Hribal ML, Perego L, Lovari S, Andreozzi F, Menghini $\mathbf{R}$, Perego C, Finzi G, (2003): Chronic hyperglycemia impairs insulin secretion by affecting insulin receptor expression, splicing, and signaling in RIN beta cell line and human islets of Langerhans.

FASEB J. ;17(10):1340-2.

21. Penumathsa S.V., Thirunavukkarasu M., Zhan L., Maulik G (2008): Resveratrol enhances GLUT-4 translocation to the caveolar lipid raft fractions through AMPK/Akt/eNOS signalling pathway in diabetic myocardium. J. Cell. Mol. Med ; 12: 2350-2361

22. Anand P., Murali K.Y., Tandon V., Murthy P.S. \& Chandra R (2010): Insulinotropic effect of cinnamaldehyde transcriptional regulation of pyruvate kinase, phosphoenolpyruvate

carboxykinase, and GLUT4 translocation in experimental diabetic rats, Chemico-Biological Interactions;186:72-81.

23. Chang P., Wong K.L., Liu I.M., Tzeng T.F., Yang T.L.\& Cheng J.T (2003): Antihyperglycemic action of agiotensin II receptor antagonist, valsartan, in streptozotocin-induced diabetic rats. Hypertension; 21 : 761-769.
24. Giffin B.F., Drake R.L., Morris R.E. \& Cardell R.R (1993): Hepatic lobular patterns of phosphoenolpyruvate

carboxykinase, glycogen synthase, and glycogen phosphorylase in fasted and fed rats. Journal of Histochemistry and Cytochemistry; 41:18491862

25. Shao J., Qiao L., Janssen R. C., Pagliassotti M.\& Friedman J. E(2005): Chronic Hyperglycemia Enhances PEPCK Gene Expression and Hepatocellular Glucose Production Via Elevated Liver Activating Protein/Liver Inhibitory Protein Ratio. Diabetes;54, 976-984

26. Meneilly G.S., Demuth H.U., McIntosh C.H.S. \& Pederson R.A (2000): Effect of ageing and diabetes on glucose-dependent insulinotropic polypeptide and dipeptidyl peptidase IV responses to oral glucose. Diabetic Medicine; 17: 346-350.

27. McKillop A.M., Duffy N.A., Lindsay J.R., O'Harte F.P., Bell P.M., Flatt P.R (2008): Decreased dipeptidyl peptidaseIV activity and glucagon-like peptide-1(7-36)amide

degradation in type 2 diabetic subjects. Diabetes Res Clin Pract; 79:79-85.

28. Ryskjaer J., Deacon C.F., Carr R.D., Krarup T., Madsbad S., Holst J. \& Vilsboll T (2006): Plasma dipeptidyl peptidase-IV activity in patients with type-2 diabetes mellitus correlates positively with HbAlc levels, but is not acutely affected by food 
intake. European $\mathrm{J}$ of Endocrinol ;155: 485-493.

29. Pala L, Mannucci E, Pezzatini A, Ciani S, Sardi J, Raimondi L, Ognibene A, Cappadona A, Vannelli BG, Rotella CM (2003): Dipeptidyl peptidase-IV expression and activity in human glomerular endothelial cells. Biochem Biophys Res Commun ;310(1):28-31.

30. Kirino Y., Sato Y., Kamimoto T., Kawazoe K., Minakuchi K.\& Nakahori Y (2009): Interrelationship of dipeptidyl peptidase IV (DPP4) with the development of diabetes, dyslipidaemia and nephropathy: a streptozotocin-induced model using wild-type and DPP4deficient rats.J Endocrinol; 200:53-61.
31. Weber A.E (2003): Dipetidyl peptidase IV inhibitors for the treatment of diabetes. Journal of Medicinal Chemistry; 47: 41354141

32. Venkatesan B., Choudhury N.G., Das F., Mahimainathan L., Kamat A., Kasinath B.S., Abboud H. E. \& Choudhury G.G (2008): Resveratrol inhibits PDGF receptor mitogenic signaling in mesangial cells: role of PTP1B. The FASEB $\mathrm{J} ; 22$ :3469-3482.

33. Ernest Y.T., Cynthia L.R., Zhang H., David W.H (2006): Adenosine downregulates DPPIV on HT-29 colon cancer cells by stimulating protein tyrosine phosphatase(s) and reducing ERK $1 / 2$ activity via a novel pathway. Am J Physiol Cell Physiol; 291: 433-444. 


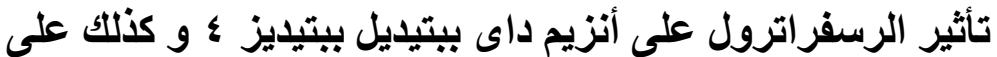

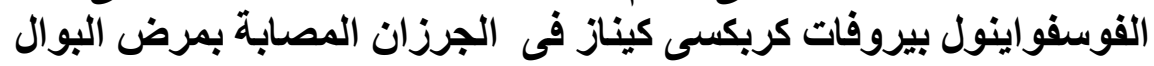 السكرى المحلث بالستربتوزوتوسين الجرزين}

سلوى الميليجى ،منال البطش،غادة عبل العليم البير

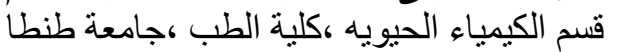

يعتبر مرض البوال السكري واحدا من الأمر اض الأيضية التي تتميز بزيادة نسبة الجلوكوز في الدم الناتج

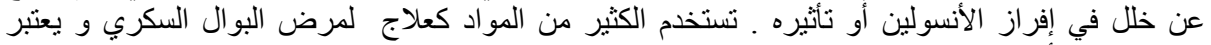

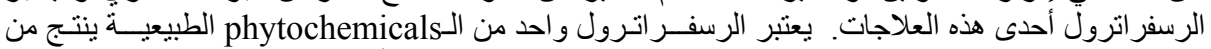

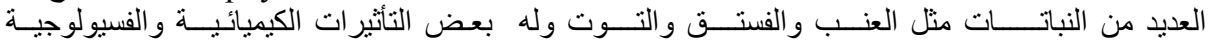

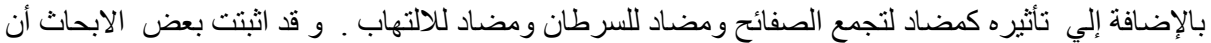

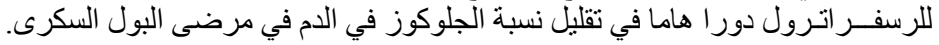

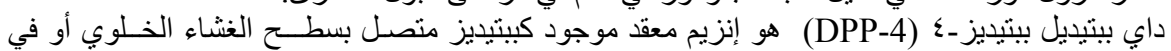

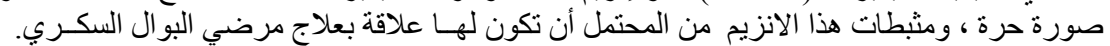

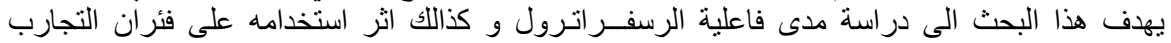

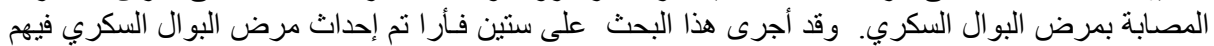

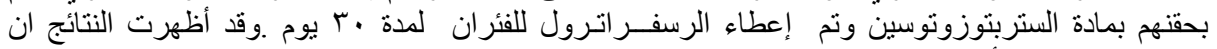

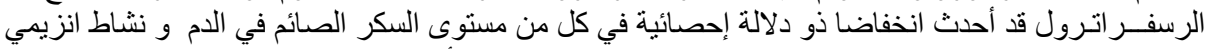

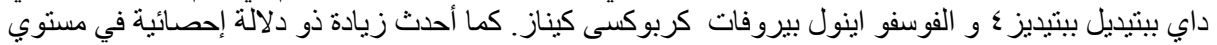

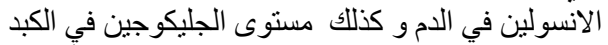

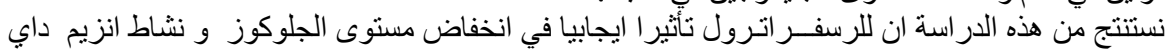

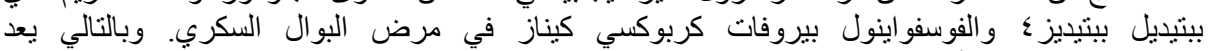

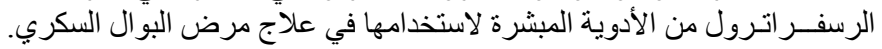

